\title{
Hipertensi dan Risiko Mild Cognitive Impairment pada Pasien Usia Lanjut
}

\section{Hypertension and Risk of Mild Cognitive Impairment in Elderly Patients}

\author{
Kasmianto Abadi* Dian Wijayanti* Ellen A. Gunawan* Marcella Erwina Rumawas* Bambang Sutrisna**
}

*Fakultas Kedokteran Universitas Tarumanegara Jakarta, **Fakultas Kesehatan Masyarakat Universitas Indonesia

\begin{abstract}
Abstrak
Mild Cognitive Impairment ( $\mathrm{MCl}$ ) meningkatkan risiko penyakit Alzheimer. Tekanan darah tinggi sering didapatkan pada beberapa pasien usia lanjut yang menderita $\mathrm{MCl}$. Penelitian potong lintang ini bertujuan untuk mengetahui hubungan antara hipertensi dan $\mathrm{MCl}$ pada lanjut usia (usia $\geq 60$ tahun) yang dipilih secara konsekutif dari pengunjung Puskesmas Joglo-I pada 12 - 18 November 2012. Kuesioner Mini Mental State Examination (MMSE) digunakan untuk skrining gangguan fungsi kognitif dan tekanan darah diukur dengan manual sfigmomanometer menurut prosedur standar. Analisis statistik menggunakan Generalized Linear Model. Dari 32 responden, rata-rata usia adalah 61 tahun dan sebanyak 53,1\% responden adalah perempuan. Hipertensi ditemukan pada 21 orang $(65,6 \%)$ dan $\mathrm{MCl}$ pada 21 orang $(65,6 \%)$. MCl didapatkan pada 17 orang (81\%) di antara 21 responden hipertensi, dan 4 orang $(36 \%)$ di antara 11 responden normotensi. Terdapat hubungan statistik yang bermakna antara hipertensi dan $\mathrm{MCl}$. Risiko mild cognitive impairment pada usia lanjut hipertensi adalah 2,2 kali lebih besar daripada mereka yang normotensi $(P R=2,2$; nilai $p=$ $0,01)$. Hubungan ini tetap bermakna setelah faktor usia, diabetes, dan stroke disetarakan (nilai $p=0,04$ ). Menurunkan kasus hipertensi dapat menjadi suatu upaya mengurangi risiko $\mathrm{MCl}$ pada usia lanjut.

Kata kunci: Hipertensi, mild cognitive impairment, usia lanjut
\end{abstract}

Abstract

Mild cognitive impairment (MCl) may increase the risk of Alzheimer's disease. Some geriatric patients with $\mathrm{MCl}$ were often identified to have high blood pressures. This cross-sectional study aimed to know association between hypertension and $\mathrm{MCl}$ in geriatric patients (age $\geq 60$ years), consecutively selected among people attending Joglo-I Primary Health Center between November 12 - 18, 2012. The Mini Mental State Examination (MMSE) questionnaires were administered to screen for cognitive impairment, blood pressures were measured using a manual sphygmomanometer according to the standard protocols. Analyzes were done using the
Generalized Linear Model procedure of 32 participants (median age: 61 years; $53.1 \%$ women), 21 respondents (65.6\%) had hypertension, and 21 others $(65.6 \%)$ had $\mathrm{MCl}$. $\mathrm{MCl}$ were identified in 17 persons $(81 \%)$ out of 21 respondents with hypertension, and in 4 persons (36\%) out of 11 respondents with normal blood pressure. Hypertension was significantly associated with $\mathrm{MCl}$. The risk that older individuals diagnosed with hypertension had $\mathrm{MCl}$ was 2.2 over that of their counterpart with normal blood pressure $(P R=2.2 ; p$ value $=0.01)$. This association remained significant after adjustment for age, diabetes, and stroke ( $p$ value $=0.04)$. Reduced hypertension may be one strategy to lower the risk of cognitive impairment among older adults.

Keywords: Hypertension, mild cognitive impairment, geriatric

\section{Pendahuluan}

Secara alamiah, setiap manusia akan menjadi tua. Seiring dengan penambahan usia, proses penuaan juga terjadi pada otak sehingga terjadi perubahan dalam kemampuan kognitif. Fungsi kognitif merupakan salah satu komponen intelektual yang paling utama dan berperan penting menentukan kualitas hidup seseorang. ${ }^{1}$ Mild cognitive impairment (MCI) merupakan kondisi gangguan kognitif yang melampaui batas perubahan yang diharapkan akibat penuaan normal (normal expected agerelated changes), namun kemampuan fungsional umum masih berfungsi normal. ${ }^{2}$

Menurut United Nation Population Division, Department of Economic and Social Affairs, jumlah populasi usia lanjut dunia ( $\geq 60$ tahun) diperkirakan hampir

Alamat Korespondensi: Marcella Erwina Rumawas, Fakultas Kedokteran Universitas Tarumanegara, Jl. Letjen S. Parman No. 1 Grogol Jakarta Barat, 11440,Hp.081280979353,e-mail: marcellarumawas@gmail.com 
mencapai 668 juta orang di tahun 2005 dan diproyeksikan menjadi 2 milyar pada tahun $2050 .{ }^{3}$ Saat itu populasi usia lanjut akan melebihi jumlah populasi anak (0 14 tahun) pertama kali dalam sejarah. Menurut laporan data demografi penduduk internasional yang dikeluarkan oleh Bureau of the Census USA, pada tahun 1990 2025 diprediksi akan terjadi kenaikan jumlah populasi usia lanjut, antara lain di Asia dari 6\% di tahun 1990 menjadi $15,3 \%$ pada tahun $2050 .{ }^{3}$ Indonesia sebagai salah satu negara berkembang, diperkirakan akan mengalami peningkatan jumlah usia lanjut, yaitu jumlah penduduk lansia sebesar 23,9 juta $(9,7 \%$ dari total penduduk) pada tahun 2010 diperkirakan akan meningkat menjadi 28,8 juta lansia pada tahun $2020(11,34 \%){ }^{1}$

Pada tahun 2002, berdasarkan penelitian yang dilakukan oleh Aging, Demographics, and Memory Study di Amerika Serikat, diperkirakan sekitar 5,4 juta orang $(22,2 \%)$ yang berusia $\geq 71$ tahun menderita mild cognitive impairment. ${ }^{2}$ Sementara itu, pada pertemuan $\mathrm{Al}$ zheimer's Association International Conference tahun 2011, disebutkan bahwa prevalensi mild cognitive impairment pada 6 negara, seperti USA, Australia, Jerman, Inggris, Swiss, dan Perancis berkisar antara 15\% - 42\%. ${ }^{3}$ United BioSource Corporation, Center for Epidemiology and Database Analytics, Lexington, MA, USA di Amerika memperkirakan prevalensi mild cognitive impairment antara $18,8 \%-28,3 \%$ pada usia lanjut. ${ }^{4}$ Pada negara di kawasan Asia, prevalensi mild cognitive impairment mencapai 17,1\%.5 Menurut Direktorat Jenderal Pelayanan Medik Kementerian Kesehatan, ${ }^{6}$ prevalensi mild cognitive impairment pada usia lanjut di Indonesia sekitar 32,4\%. Di Jakarta, misalnya di wilayah kerja Puskesmas Kelurahan Joglo I, Jakarta Barat, berdasarkan data bulan Januari - Oktober 2012, didapatkan 80 orang usia lanjut yang menderita mild cognitive impairment dari total 322 orang usia lanjut yang datang berobat.

Selain karena proses degeneratif, risiko mild cognitive impairment dapat diakibatkan oleh berbagai faktor seperti jenis kelamin, obesitas, merokok, hipertensi, diabetes melitus, hiperlipidemia, stroke, radikal bebas, trauma otak, infeksi serebral, epilepsi, tumor otak, gangguan jantung (termasuk gagal jantung kronik dan aritmia), dan genetik. ${ }^{7}$ Di Puskesmas Kelurahan Joglo I, mild cognitive impairment sering ditemukan pada pasien usia lanjut dengan hipertensi, tetapi data tersebut masih sangat terbatas, khususnya pada usia lanjut Indonesia. Oleh karena itu, penelitian ini bertujuan untuk mengetahui hubungan hipertensi dengan faktor yang dapat meningkatkan risiko mild cognitive impairment khususnya pada lansia di Puskesmas Kelurahan Joglo I. Penelitian ini diharapkan dapat membantu pencegahan terjadinya mild cognitive impairment pada pasien usia lanjut sehingga kualitas hidup dapat menjadi lebih baik.

\section{Metode}

Penelitian dilakukan dengan desain studi analitis observasional potong lintang untuk mengetahui hubungan antara hipertensi dengan mild cognitive impaiment pada usia lanjut. Populasi adalah semua pasien yang berobat di Puskesmas Joglo I. Sebanyak 32 responden dipilih dari antara pasien yang datang ke Puskesmas Kelurahan Joglo I Jakarta Barat pada tanggal 12 - 18 November 2012 dengan cara consecutive nonrandom sampling, yaitu mereka yang berusia $\geq 60$ tahun, tamat sekolah dasar, dapat memahami dan menulis bahasa Indonesia, tidak menderita demensia dan tidak mempunyai riwayat gangguan jantung.

Data dikumpulkan dengan metode wawancara oleh dua orang peneliti secara independen menggunakan dua set kuesioner yang terpisah. Dengan menggunakan kuesioner I, peneliti A menanyakan responden riwayat tekanan darah tinggi, kencing manis, stroke, cedera kepala berat hingga tidak sadarkan diri, kejang, demam hingga tidak sadarkan diri dan sakit kepala berat terus menerus yang tidak sembuh dengan pengobatan. Peneliti A juga melakukan pengukuran tekanan darah responden. Responden dinyatakan menderita hipertensi apabila pada keadaan istirahat tekanan darah sistolik $\geq 140 \mathrm{mmHg}$ dan/ atau tekanan darah diastolik $\geq 90 \mathrm{mmHg}$. Gejala mild cognitive impairment diidentifikasi dengan teknik wawancara oleh peneliti B dengan menggunakan kuesioner baku MMSE. ${ }^{2}$ MMSE merupakan instrumen penapis untuk mendeteksi kemungkinan gangguan kognitif yang terdiri dari pertanyaan mengenai orientasi waktu dan tempat, pengenalan benda (registrasi), perhitungan, ingatan, bahasa (penyebutan, pengulangan, pengertian, dan menulis) dan visuospasial (konstruksi). Responden dinyatakan menderita mild cognitive impairment apabila skor MMSE berkisar antara 24 - 27 dan aktivitas sehari- harinya tidak terganggu. Apabila skor MMSE < 24 , responden dinyatakan demensia dan tidak diikutsertakan dalam penelitian ini.

Penelitian ini menggunakan analisis asosiasi statistik. Variabel dependent adalah mild cognitive impairment dan variabel independent adalah hipertensi. Responden diklasifikasikan atas mereka yang dinyatakan mengalami gangguan mild cognitive impairment (skor MMSE 24 27) dan mereka dengan fungsi kognitif normal (skor MMSE 28 - 30). Data hasil pengukuran tekanan darah dibagi menjadi dua kategori, yaitu hipertensi (tekanan darah $\geq 140 / 90 \mathrm{mmHg}$ ) atau normal (tekanan darah < $140 / 90 \mathrm{mmHg}$ ). Faktor-faktor risiko lainnya yang berperan sebagai faktor perancu potensial yaitu usia, jenis kelamin, riwayat stroke, dan Diabetes Melitus tipe 2.

Besar risiko mild cognitive impairment antara responden yang hipertensi dibandingkan dengan yang normotensi dinyatakan dalam ukuran risiko absolut dan risiko relatif. Digunakan uji statistik generalized linear 
models dengan model binary logistic untuk mengetahui adakah hubungan antara hipertensi dan mild cognitive impairment. Pengaruh usia, riwayat penyakit Diabetes Melitus tipe 2 dan stroke sebagai faktor perancu potensial terhadap asosiasi antara hipertensi dan mild cognitive impairment diuji pengaruhnya berdasarkan metode analysis of covariance dengan menggunakan prosedur generalized linear models-binary logistic. Nilai $\mathrm{p}<0,05$ dinyatakan sebagai adanya asosiasi statistik.

\section{Hasil}

Dari hasil penelitian didapatkan total responden sebanyak 32 orang, 17 orang $(53,1 \%)$ di antaranya perempuan. Pada 32 responden diketahui bahwa nilai tengah usia adalah 61 tahun dengan responden termuda berusia 55 tahun dan tertua berusia 84 tahun. Dari 32 responden tersebut, didapatkan nilai tengah (minimum dan maksimum) tekanan darah sistol dan diastol berturutturut adalah 140 (110 dan 180) $\mathrm{mmHg}$ dan 80 (60 dan 150) $\mathrm{mmHg}$. Di antara 32 orang responden pada penelitian ini, didapatkan responden dengan mild cognitive impairment sebanyak 21 orang $(65,6 \%)$, responden dengan hipertensi sebanyak 21 orang $(65,6 \%)$, responden dengan Diabetes Melitus tipe 2 sebanyak 3 orang $(9,4 \%)$ dan responden dengan stroke sebanyak 1 orang $(3,1 \%)$. Pada penelitian ini, tidak ada responden dengan riwayat epilepsi, kejang, tumor otak, infeksi serebral, ataupun trauma kepala.

Pada 21 responden yang didiagnosa hipertensi, nilai tengah umur relatif sebanding dengan 11 responden yang mempunyai tekanan darah normal, walaupun umur termuda dan usia tertua berada di kelompok tersebut. Pada responden dengan hipertensi, didapatkan lebih banyak perempuan memiliki tekanan sistol dan diastol lebih tinggi, dan juga lebih banyak yang mempunyai riwayat diabetes melitus tipe 2 maupun stroke daripada mereka dengan tekanan darah normal (Tabel 1).

Pada 21 responden yang hipertensi, didapatkan 17 responden $(81 \%)$ yang terdiagnosis menderita mild $\operatorname{cog}$ nitive impairment, sedangkan pada 11 responden dengan tekanan darah normal, 4 responden (36\%) dideteksi mild cognitive impairment. Dari jumlah tersebut, selisih risiko mild cognitive impairment antara responden usia lanjut dengan hipertensi dibandingkan dengan responden normotensi sebesar 45\% (risk difference / $\mathrm{RD}=45 \%$ ). Hal itu berarti, responden usia lanjut yang hipertensi mempunyai risiko 2,2 kali lebih besar untuk menderita mild cognitive impairment dibandingkan dengan mereka yang tidak hipertensi, atau dengan kata lain, pada usia lanjut, hipertensi meningkatkan risiko mild cognitive impairment sebesar 120\% (Prevalence ratio / $\mathrm{PR}=2,2)($ Gambar 1$)$.

Pada penelitian ini, didapatkan hubungan yang bermakna secara statistik antara hipertensi dan mild
Tabel 1. Karakteristik Responden

\begin{tabular}{lll}
\hline Variabel $^{*}$ & Hipertensi & Normotensi \\
\hline Usia (tahun) & $61(55 ; 84)$ & $61(60 ; 81)$ \\
Perempuan $(\%)^{\dagger}$ & $10(47,6)$ & $7(63,6 \%)$ \\
Tekanan sistol $(\mathrm{mmHg})$ & $140(120 ; 180)$ & $120(110 ; 130)$ \\
Tekanan diastol $(\mathrm{mmHg})$ & $90(60 ; 150)$ & $70(70 ; 85)$ \\
Diabetes Melitus tipe 2(\%) & $3(14,3)$ & 0 \\
Stroke $(\%)^{\dagger}$ & $1(4,8)$ & 0 \\
\hline
\end{tabular}

Keterangan: * Nilai adalah nilai tengah (minimum; maksimum), kecuali dinyatakan sebaliknya, $\uparrow$ Nilai adalah jumlah (persentase)

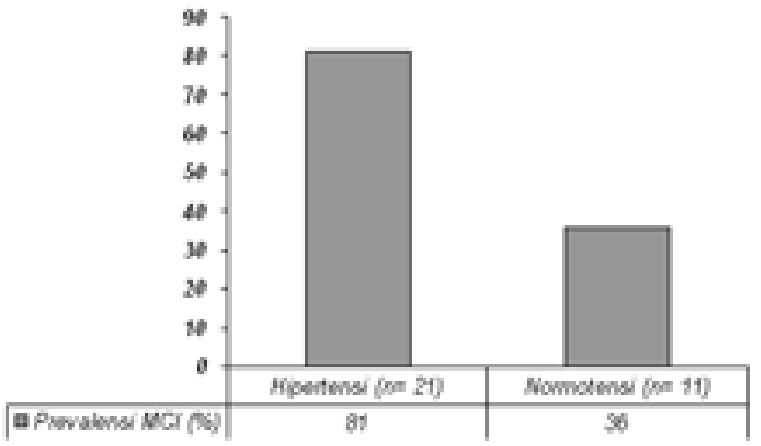

Gambar 1. Perbandingan Prevalensi Mild Cognitive Impairment pada Responden Lanjut Usia dengan Hipertensi atau Normotensi

Tabel 2. Asosiasi Antara Hipertensi dan Mild Cognitive Impairment

\begin{tabular}{lcc}
\hline Model Statistik* $^{*}$ & Prevalence Ratio & Nilai p \\
\hline Model dasar & 2,2 & 0,01 \\
Model 1 & 2,3 & 0,04 \\
Model 2 & 2,3 & 0,04 \\
\hline
\end{tabular}

*Keterangan:

Model dasar: hipertensi (vs normotensi); Model 1: model dasar + usia dan jenis kelamin; Model 2: model 1 + riwayat Diabetes Melitus tipe 2 dan stroke

cognitive impairment yaitu risiko mild cognitive impairment pada usia lanjut hipertensi adalah 2,2 kali di atas risiko mereka yang tidak hipertensi $(\mathrm{PR}=2,2$; nilai $\mathrm{p}=$ $0,01)$. Hubungan bermakna antara hipertensi dan mild cognitive impairment tersebut tidak berubah setelah faktor risiko umur, jenis kelamin, Diabetes Melitus, dan stroke disetarakan $(\mathrm{PR}=2,3$; nilai $\mathrm{p}=0,04)$ (Tabel 2).

\section{Pembahasan}

Hasil penelitian ini menemukan hubungan bermakna antara hipertensi dan mild cognitive impairment (nilai $\mathrm{p}$ $=0,01$ ). Temuan penelitian ini selaras dengan penelitianpenelitian terdahulu. Hasil penelitian kohort prospektif yang dilakukan di Manhattan, New York pada 918 pasien berusia 65 tahun atau lebih yang datang berobat di RS dan tidak menderita mild cognitive impairment atau demensia pada awalnya dengan masa observasi tahun 1992 - 1996, menunjukkan bahwa 209 responden 
$(22,8 \%)$ menderita hipertensi dan mild cognitive impairment. ${ }^{8}$ Mild cognitive impairment diketahui sebagai keadaan transisi dari penurunan fungsi kognitif yang normal akibat proses penuaan ke gangguan fungsi kognitif yang lebih progresif (demensia). ${ }^{9}$ Pasien usia lanjut dengan mild cognitive impairment yang disertai dengan gangguan perilaku seperti depresi, apatis, gelisah, dan agitasi, lebih rentan untuk berkembang menjadi demensia Alzheimer daripada pasien tanpa perilaku tersebut. ${ }^{10}$

Individu dengan gangguan kognitif ringan mampu berfungsi dalam kegiatan sehari-hari, tetapi mengalami gangguan dalam kemampuan memori, bahasa, dan kemampuan visuospasial ataupun fungsi eksekutif. ${ }^{11} \mathrm{Pe}$ nurunan kemampuan memori dapat ditandai dengan tidak mampu mengingat apa yang telah dilakukan kemarin. Gangguan berbahasa atau kesulitan dalam berkomunikasi termasuk ketidakmampuan untuk mengingat dan mengintegrasikan kata-kata dalam sebuah percakapan atau untuk mengikuti suatu percakapan. Penurunan kemampuan visuospasial, yaitu penurunan kemampuan yang terkait dengan akurasi dalam estimasi seperti membuat perkiraan jarak, volume, dan posisi yang tepat, sedangkan penurunan fungsi eksekutif seperti kesulitan dengan pengambilan keputusan, perencanaan dan pengorganisasian. ${ }^{12}$ Akan tetapi, dalam praktiknya, diagnosis mild cognitive impairment sering kali sukar ditegakkan secara pasti karena tidak menunjukkan gejala yang khas. Tahap awal mild cognitive impairment pada individu muncul sebagai perubahan memori yang mungkin tidak selalu terlihat, kecuali diamati oleh seorang profesional yang terlatih, atau dikenali oleh anggota keluarga atau teman yang dekat dengan penderita. ${ }^{13}$

Hipertensi sering dihubungkan dengan penurunan fungsi kognitif, salah satunya karena peningkatan tekanan darah memicu timbulnya lesi di area putih subkortikal otak. Hipertensi juga menimbulkan aterosklerosis. Pada kondisi ini, penebalan dinding arteri dan penurunan permeabilitas dinding pembuluh darah mengakibatkan meningkatnya transport lipoprotein ke dalam dinding arteri, meningkatnya proliferasi sel otot polos serta sintesis matriks molekul ekstra sel. Hal tersebut menyebabkan aliran darah ke otak menurun, terbentuknya lesi pada jaringan otak akibat kerusakan endotel dan insufisiensi aliran darah serebral akibat iskemia pada arteri serebral otak. Kondisi ini pada akhirnya menyebabkan kerusakan jaringan otak seperti yang ditemukan pada mild cognitive impairment. ${ }^{14}$

Pada penelitian ini, hubungan antara hipertensi dan mild cognitive impairment melemah, tetapi tetap bermakna setelah faktor-faktor risiko lainnya dari mild cognitive impairment seperti usia, jenis kelamin, Diabetes Melitus dan stroke disetarakan (nilai $\mathrm{p}=0,04$ ). Dengan bertambahnya usia, terjadi proses degeneratif pada otak yang ditandai dengan adanya atrofi otak. Atrofi pada hipokampus mengakibatkan terjadinya penurunan fungsi memori yang menyebabkan mild cognitive impairment. Berdasarkan studi kohort prospektif di Olmsted County Minnesota, ${ }^{15}$ yang melibatkan 1.450 responden, insidens MCI lebih tinggi pada pria $72,4 \%$ dibandingkan wanita $57,3 \%$. Stroke dapat menyebabkan terjadinya iskemia pada sel-sel otak. Hal ini akan menyebabkan terjadinya kegagalan pompa $\mathrm{NA}^{+}-\mathrm{K}^{+}$ATP-ase, yang akan menyebabkan peningkatan $\mathrm{Ca}^{2+}$ intraseluler dan peningkatan neurotransmiter eksitatorik seperti glutamat. Risiko peningkatan neurotransmiter eksitatorik ini lebih tinggi pada usia yang lebih tua. Sedangkan, meningkatnya pelepasan glutamat mengakibatkan inisiasi apoptosis pada sel-sel neuron terutama sel-sel hipokampus sehingga menyebabkan mild cognitve impairment. ${ }^{15}$ Diabetes Melitus meningkatkan risiko hipertensi maupun mild cognitve impairment. Melalui mekanisme nonvaskuler, hiperglikemia pada Diabetes Melitus menyebabkan inaktivasi protein antioksidan seperti superoksid dismutase. Hal ini mengurangi ketahanan antioksidan dan berujung pada neurotoksisitas sel-sel neuron di susunan saraf pusat, termasuk neuron yang bertanggung jawab dalam fungsi kognitif. Melalui mekanisme vaskuler, hiperglikemia menyebabkan terjadinya aterosklerosis. Proses aterosklerosis akhirnya akan menimbulkan gangguan perfusi otak sehingga terjadi iskemia dan kematian pada jaringan otak, yang berujung pada mild cognitve impairment. ${ }^{14}$ Pada penelitian ini, tidak didapatkan responden dengan riwayat epilepsi, kejang, tumor otak, infeksi serebral, trauma kepala, ataupun riwayat gangguan jantung termasuk gagal jantung kronik dan arimia. Dengan demikian, kemungkinan adanya pengaruh faktor-faktor tersebut terhadap hubungan antara hipertensi dan risiko mild cognitive impairment dapat disingkirkan.

Radikal bebas juga dapat berpengaruh terhadap patofisiologi mild cognitive impairment. Radikal bebas merupakan produk fisiologis dalam berbagai kegiatan metabolisme di dalam tubuh. Pada umumnya, molekul pada tubuh merupakan molekul yang bersifat nonradikal, yaitu molekul yang selalu mempunyai elektron berpasangan. Radikal bebas mempunyai karakter lebih mudah berikatan dengan molekul nonradikal yang memiliki berat jenis besar (makroseluler), seperti protein, karbohidrat, asam nukleat, enzim, dan lipid. Selanjutnya oksidan dan reactive oxygen species, yaitu ikatan antara radikal bebas dengan molekul nonradikal, menimbulkan reaksi oksidatif berkelanjutan. Kondisi ini merusak berbagai makroseluler sehingga memengaruhi homeostasis normal di dalam sel dan akhirnya mengakibatkan berbagai proses degeneratif. Sel dan jaringan yang paling rentan terhadap stres oksidatif adalah sel otak. Stres oksidatif dapat mengakibatkan kerusakan sel glia dan 
neuron yang dapat berdampak pada penurunan fungsi kognitif. 15

Penelitian ini tidak terlepas dari beberapa keterbatasan. Pertama, desain penelitian potong lintang membatasi kemampuan meneliti hubungan temporal sebab akibat antara hipertensi dan mild cognitive impairment. Kedua, bias seleksi tidak dapat disingkirkan karena pengambilan sampel dengan cara consecutive nonrandom sampling sehingga sampel hanya diambil dari pasien pengunjung Puskesmas Kelurahan Joglo I yang memenuhi kriteria inklusi. Akibatnya, distribusi faktor risiko dan penyakit pada sampel tidak mewakili keadaan yang sesungguhnya pada populasi di wilayah kerja Puskesmas Kelurahan Joglo I. Kondisi tersebut dapat membatasi aplikasi langsung hasil penelitian ini kepada populasi di wilayah tersebut. Ketiga, kemungkinan terjadinya misklasifikasi nondiferensial dalam mengklasifikasikan mild cognitive impairment akibat penggunaan MMSE sebagai instrumen diagnostik. MMSE merupakan instrumen penapis (skrining) mild cognitive impairment. Beberapa penelitian untuk menguji sensitivitas dan spesifitas MMSE untuk mendiagnosa cognitive impairment yang bervariasi. Pada penelitian dengan 70 sampel didapatkan sensitivitas $81 \%$ dan spesifitas 83\%. Penelitian lain dengan sampel 556 mendapatkan sensitivitas $65 \%$ dan spesifitas $96 \%$. Sedangkan, penelitian dengan sampel sebanyak 2.000 mendapatkan sensitivitas $86 \%$ dan spesifitas $92 \% .{ }^{15}$ Nilai sensitivitas dan spesifisitas yang relatif tinggi ini mendukung validitas penggunaan MMSE sebagai intrumen diagnostik mild cognitive impairment pada tingkat populasi sebagaimana penggunaannya pada penelitian ini yang berbasiskan komunitas. Keempat, besar sampel pada penelitian yang kurang dari sampel minimum sehingga tidak tertutup kemungkinan didapatkannya hasil secara kebetulan. Kelima, kemungkinan terjadinya bias perancu akibat keterbatasan informasi mengenai beberapa faktor risiko mild cognitive impairment lainnya seperti riwayat merokok, obesitas, dan hiperlipidemia.

\section{Kesimpulan}

Penelitian $\mathrm{p}$ otong lintang ini menunjukkan adanya hubungan yang bermakna secara statistik antara hipertensi dengan mild cognitive impairment pada usia lanjut yaitu risiko mild cognitive impairment pada usia lanjut hipertensi 2,2 kali di atas risiko mereka yang tidak hipertensi ( $P R=2,2$; nilai $p=0,01)$. Hubungan bermakna antara hipertensi dan mild cognitive impairment tersebut tidak berubah setelah faktor risiko umur, diabetes melitus dan stroke disetarakan $(\mathrm{PR}=2,3$; nilai $\mathrm{p}=$ $0,04)$.

\section{Saran}

Dibutuhkan studi-studi lanjutan dengan desain lain seperti kasus-kelola, kohort untuk mengetahui dengan lebih pasti hubungan hipertensi dengan mild cognitive impairment pada usia lanjut. Kontrol tekanan darah dan deteksi dini hipertensi merupakan salah satu strategi untuk menurunkan risiko mild cognitive impairment pada pasien lanjut usia di Puskesmas Kelurahan Joglo I, Jakarta Barat khususnya maupun di masyarakat Indonesia pada umumnya.

\section{Daftar Pustaka}

1. Darmojo B. Demografi dan epidemiologi populasi lanjut usia. Dalam: Darmojo B, Hartono HH, Pranarka K, editor. Buku ajar geriatri. Edisi ke-4. Jakarta: Balai Penerbit Fakultas Kedokteran Universitas Indonesia; 2010. h. 35-55.

2. Plassman LB, Langa KM, Fisher GG. Prevalence of cognitive impairment without dementia in the United States. National Institutes of Health [manuscript on internet]. 2008 [cited 2011 Nov13]; 427-34. Available from: http://www.ncbi.nlm.nih.gov/pmc/articles/PMC2670458.

3. Alzheimer's Association. Insight into global incidence and prevalence of mild cognitive impairment. Alzheimer's Association International Conference [online]. 2011 [cited 2011 November 13]. Available from: http://www.news-medical.net/news/20110719/Insight-into-globalincidence-and-prevalence-of-mild-cognitive-impairment.aspx.

4. Warda A, Arrighib HM, Michelsa S, Cedarbaum JM. Mild cognitive impairment: disparity of incidence and prevalence. Alzheimer's \& Dementia Journal. 2012; 8 (12): 14-21.

5. Keputusan Menteri Kesehatan Republik Indonesia Republik Indonesia, 2010, Nomor 264: Pedoman penanggulangan masalah kesehatan intelegensia akibat gangguan degeneratif [diakses tanggal 14 November 2011]. Diunduh dari: http://www.hukor.depkes.go.id/up_prod_kepmenkes/KMK\%20No.\%20264\%20ttg\%20Intelegensia\%20Degeneratif.

6. Petersen RC. Clinicial practive. Mild cognitive impairment. The New England Journal of Medicine. 2011364 (23): 2227-34.

7. Reitz C, Tang MX, Manly J. Hypertension and the risk of mild cognitive impairment. Archives Neurology [serial on internet]. 2007 [cited 2011 November 16]; 64 (12): 1734-40. Available from: http://archneur.jamanetwork.com/article.aspx?articleid=794911.

8. Landau SM, Harvey D, Madison CM, Reiman EM, Foster NL, Aisen PS. Comparing predictors of conversion and decline in mild cognitive impairment. Neurology. 2010; 75 (3): 230-8.

9. Andreescu C, Aizenstein HJ. Amnestic disorders and mild cognitive impairment. In: Sadock BJ, Sadock VA, Kaplan and Sadock's, editors. Comprehensive textbook of psychiatry. Philadelphia: Lippincott Williams and Wilkins; 2009. p. 1198 - 206.

10. Soejono. Pengkajian paripurna pada pasien geriatri. In: Sudoyo AW, Setiyohadi B, editors. Buku ajar penyakit dalam. Edisi ke-5. Jakarta: Balai Penerbit Fakultas Kedokteran Universitas Indonesia; 2009. p. 768773.

11. Artero S, Ancelin ML, Portet F, Dupuy A, Berr C, Dartigues JF, et al. Risk profiles for mild cognitive impairment and progression to dementia are gender specific. Journal of Neurology, Neurosurgery and Psychiatry. 2008; 79: 979-84. 
12. Molano J, Boeve B, Ferman T, Smith G, Parisi J, Dickson D, et al. Mild cognitive impairment associated with limbic and neocortical lewy body disease: a clinicopathological study. Brain. 2009; 133 (2): 540-56

13. Petersen RC, Roberts RO, Knopman DS, Boeve BF, Geda YE, Ivnik RJ, et al. Mild cognitive impairment: ten years later. Archives of Neurology. 2009; 66: 1447-55.
14. Roberts RO, Geda YE, Knopman DS, Cha RH, Pankratz VS, Boeve BF, et al. The incidence of mci differs by subtype and is higher in men: The Mayo Clinic Study of Aging. Neurology. 2012; 78 (5): 342-51.

15. Diniz BS, Yassuda MS, Nunes PV, Radanovic M, Forlenza OV. Minimental state examination performance in mild cognitive impairment subtypes. International Psychogeriatry. 2009; 19: 647-56. 